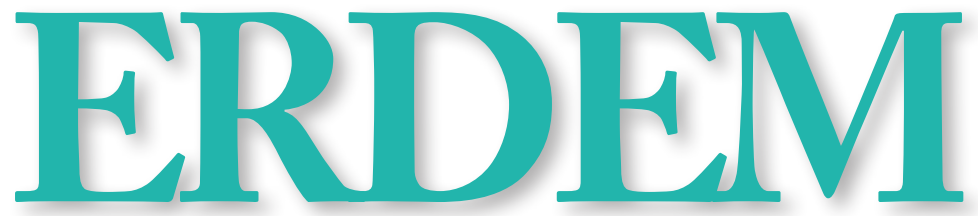

İNSAN VE TOPLUM BİLİMLERİ DERGİSİ

Münire Kevser BAŞ

Poetik Bir Metin Olarak Ebubekir Eroğlu’nun

"Yol Elçisi" Şiiri

Evşen ÇERKEŞLİ

Kurtuluş Savaşı ve Cumhuriyet İdeolojisini Edebî

Düzlemde Okumak: Dikmen Yıldızı Örneği

Hivren DEMIR ATAY

Tekerlerden Tekrarlara Gamba’da Dönüş ve Dönüşüm

Selma GÜNAYDIN

Edebî Bir Siyer Örneği Olarak Cöle İnen Nửun

Kaynakları

Mustafa GÜNDÜZ

Türk Eğitim Sisteminde Aşırı Militarist

Uygulamanın Başlaması (1926-1947)

Nagihan GÜR

Edebiyat Tarihi Yazımında Bir Kaynak Olarak

Takrizler ve Sıra Dışı İki Örnek

Osman ÖZEN - Kemalettin KUZUCU

Türk Basın Tarihinde Artin Asaduryan Matbaası ve

Matbaada Basılan Süreli Yayınlar

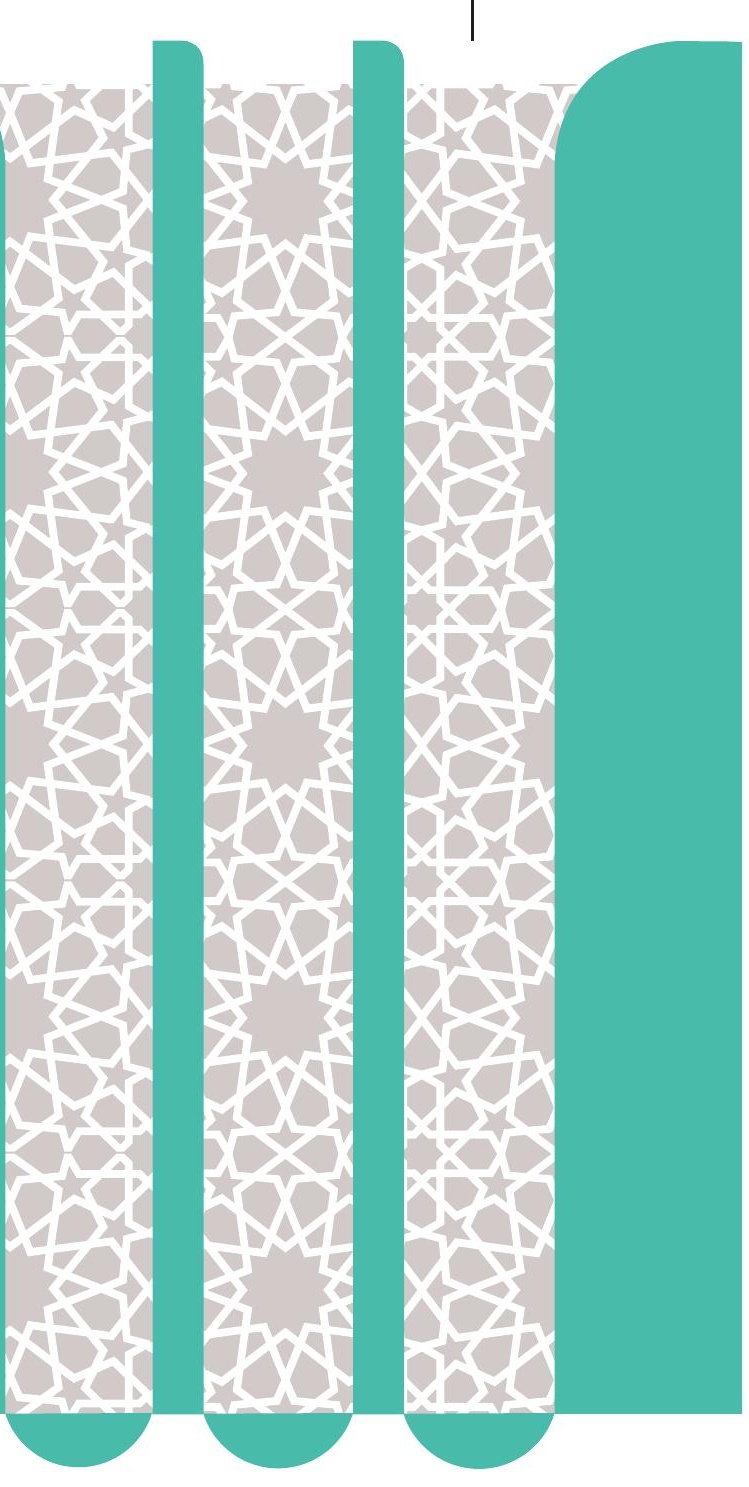




\section{ERDEM}

İNSAN VE TOPLUM BİLIMLERI DERGİSİ

JOURNAL OF HUMANITIES AND SOCIAL SCIENCES

Atatürk Kültür Merkezi tarafindan yayımlanan Erdem, insan ve toplum bilimleri alanında makalelere yer veren, hakemli bir uluslararası dergidir.

Haziran ve aralık aylarında olmak üzere yılda iki sayı çıkar.

Erdem, EBSCO, MLA ve TÜBİTAK/ULAKBİM SBVT tarafindan dizinlenmektedir.

Erdem, published by Atatürk Culture Centre, is a peer-reviewed international journal that publishes articles on humanities and social sciences.

It is published twice a year in June and December

Erdem is indexed in EBSCO, MLA and TÜBİTAK/ULAKBİM SBVT.

Görüş ve önerileriniz için editörlerimizle iletişime geçebilirsiniz.

For comments and suggestions you may contact our editors.

erdemdergisi@gmail.com 
Kültür yayıncılığın öncüsünden

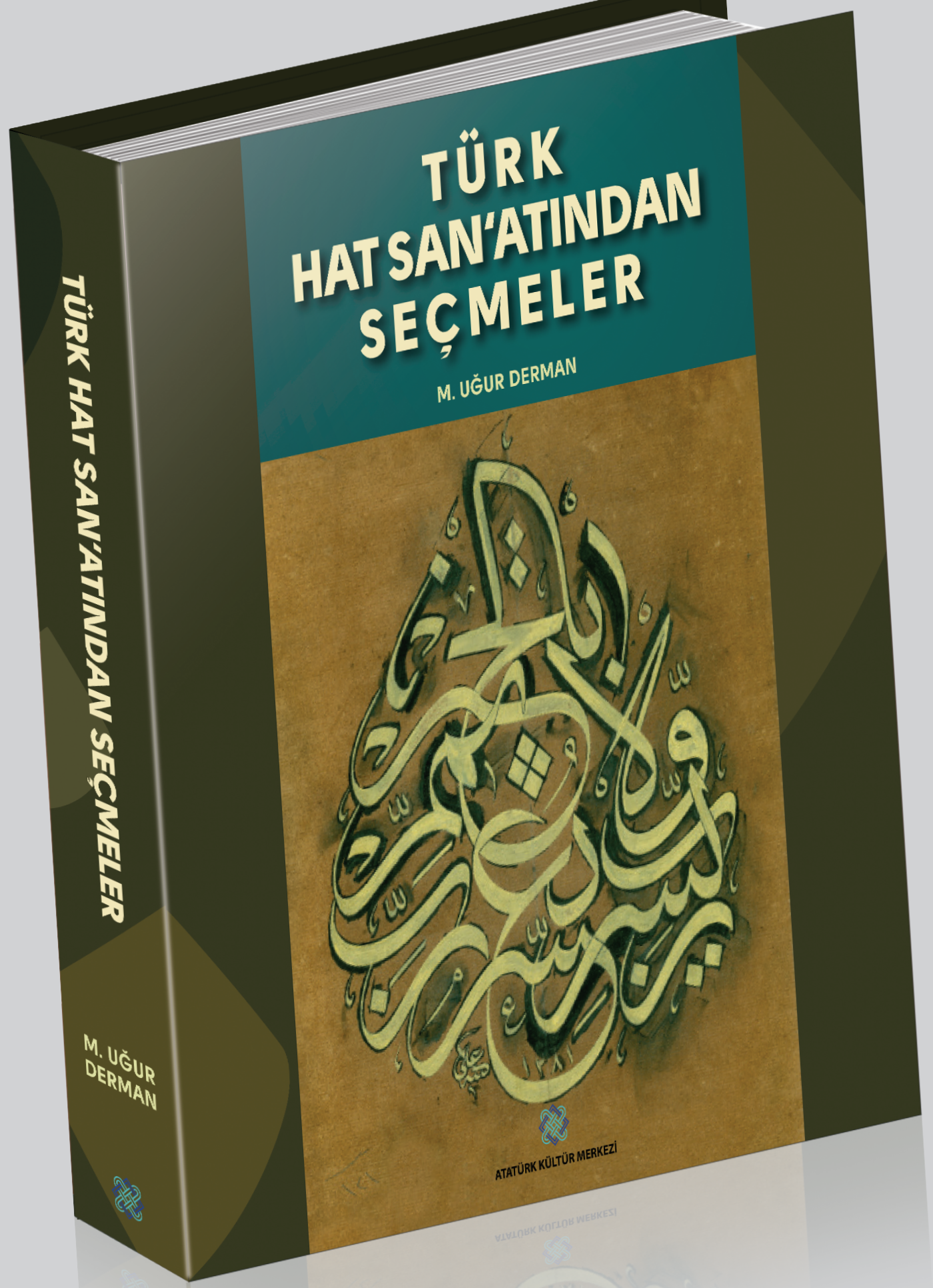




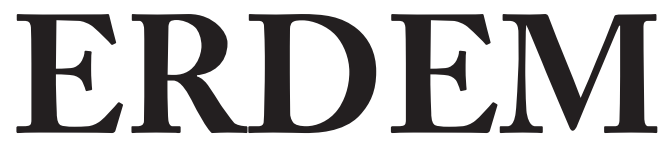

İnsan ve Toplum Bilimleri Dergisi

Journal of Humanities and Social Sciences

SAYI 71-72 • ARALIK 2016 - HAZIRAN 2017

ATATÜRK KÜLTÜR, DIL VE TARIH YÜKSEK KURUMU ATATÜRK SUPREME COUNCIL FOR CULTURE, LANGUAGE AND HISTORY

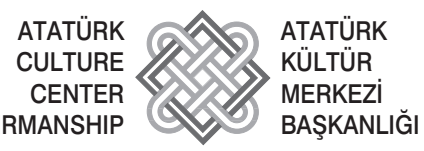




\section{ERDEM}

İnsan ve Toplum Bilimleri Dergisi

Journal of Humanities and Social Sciences

\section{DANIŞMA KURULU/ADVISORY BOARD}

Prof. Dr. Hakkı ACUN (Gazi Üniversitesi)

Prof. Dr. Hüseyin AKKAYA (Cumhuriyet Üniversitesi)

Prof. Dr. Âdem CEYHAN (Celâl Bayar Üniversitesi)

Prof. Dr. Hamza ÇAKIR (Erciyes Üniversitesi)

Prof. Dr. Mustafa ÇiçEKLER (İstanbul Medeniyet Üniversitesi)

Prof. Dr. Nurettin DEMIR (Hacettepe Üniversitesi)

Prof. Dr. Hayati DEVELI (İstanbul Üniversitesi)

Prof. Dr. Esin KÂHYA (Emekli öğretim üyesi)

Prof. Dr. Ramazan KAPLAN (Ankara Üniversitesi)

Prof. Dr. Alâattin KARACA (Muğgla Üniversitesi)

Prof. Dr. Selçuk MÜLAYIM (Marmara Üniversitesi)

Prof. Dr. Ahmet Yaşar OCAK (TOBB Üniversitesi)

Prof. Dr. Öcal OĞUZ (Gazi Üniversitesi)

Doç. Dr. Mehmet BİRGÜL (Uludağ Üniversitesi)

Doç. Dr. İdris Nebi UYSAL (Karamanoğlu Mehmetbey Üniversitesi) 


\section{ERDEM}

SAYI 71-72 • 2016-2017

Kurucu/Founder

Ord. Prof. Dr. Aydın SAYILI (1913-1993)

Sahibi/Owner

Atatürk Kültür Merkezi adına Başkan

Zeki ERASLAN

Yayın Kurulu/Editorial Board Prof. Dr. Muhammet HEKIMOĞLU

Prof. Dr. Güray KIRPIK

Doç. Dr. Bilal ÇAKICI

Uzm. Ömer ÇAKIR

Yüksek Kurum Uzm. Murat Altan ERİK

Yüksek Kurum Uzm. Yrd. Ömer GÖK

Yazı İşleri Müdürü/Managing Editor

Başkan Yardımcısı Şaban ABAK

Editörler/Editors

Yüksek Kurum Uzm. M. Altan ERİK

Uzm. Yrd. Ömer GÖK

İngilizce Özetler/English Abstracts Ayşegül ÖZDOĞAN

Yönetim Yeri/Managing Office Ziyabey Caddesi No: 19 Balgat 06520 Ankara, TÜRKIYE

Tel.: +903122843425 erdemdergisi@gmail.com www.akmb.gov.tr

GrafikTasarım/Graphic Design Grafiker Grafik-Ofset Matbaacılık

Reklamcılık San. ve Tic. Ltd. Şti Mustafa YAVUZ

Bask1/Print

Grafiker Grafik-Ofset Matbaacılık Reklamcılık San. ve Tic. Ltd. Şti. www.grafiker.com.tr

Yayın Türü/Publication Type Süreli Yayın

Yılda İki Sayı Çıkar ISSN 1010-867X

Baskı Tarihi/Print Date Haziran 2017
Değerli okurlar,

Erdem'in 71 ve 72 . sayıları ile karşınızdayız. Ülkemizde yaşanan hain darbe girişimi, tüm kamu kurumlarını derinden etkilediği gibi Kurum olarak bizim çalışmalarımızı da sekteye uğratmıştır. Bu sebeple Haziran 2016'da çıkaracağımız 71. sayıyı ancak 72. sayı ile birlikte siz değerli okuyucularımıza takdim ediyor, bundan sonra böyle gecikmelerin yaşanmamasını umuyoruz.

Sevgili okurlar, bu sayımızda edebiyat, basın ve eğitim tarihini ilgilendiren yazıların yanı sıra Selma Günaydın’ın “Edebî Bir Siyer örneği Olarak Çöle İnen Nur'un Kaynakları"nda Necip Fazıl Kısakürek; Doç. Dr. Münire Kevser Baş'ın "Poetik Bir Metin Olarak Ebubekir Eroğlu'nun 'Yol Elçisi' Şiiri”nde ise Ebubekir Eroğlu gibi kültür dünyamızın öncü isimlerinin eserleriyle ilgili inceleme yazılarını da muhtevi yedi makaleye yer verilmiştir. Kültür ve edebiyat tarihimize 1ş1k tutan birbirinden değerli bu makalelerin siz değerli okurlarımız tarafindan ilgiyle karşılanacağını ümit ediyoruz.

Dün olduğu gibi bugün de Erdem dergisi niceliği değil, niteliği önemseyen anlayışını devam ettiriyor. İki sayı birlikte çıkarmamıza rağmen bu anlayışımızdan yine taviz vermedik. Onlarca makaleden oluşan ancak okunmayan dergiler arasinda olmaktansa sayica az fakat özgün ve yetkin makaleler içeren bir dergi olmak tercihimizdir. Bu şiarla hareket ediyor ve makale seçimlerinden hakem atamalarına değin birçok aşamayı titizlikle yürütüyoruz. Bu noktada sizlerden gelecek eleştirilere de açık olduğumuzu bildirmek isteriz. Daha iyiye ve güzele yol almak için tüm yazar ve okurlarımızin desteğine talibiz.

Gelecek sayılarda buluşmak dileğiyle.

İyi okumalar,

\section{Şaban ABAK}




\section{ERDEM}

Say1 71-72 • Aralık 2016-Haziran 2017

\section{İÇINDEKILER/CONTENTS}

\section{Münire Kevser BAŞ}

Poetik Bir Metin Olarak Ebubekir Eroğlu'nun “Yol Elçisi” Şiiri

Ebubekir Eroğlu's Poem "Yol Elçisi” As a Poetic Text

\section{Evşen ÇERKEŞLI}

Kurtuluş Savaşı ve Cumhuriyet İdeolojisini Edebî

Düzlemde Okumak: Dikmen Yıldızı Örneği

The War of Independence and The Republican Ideology in

Literary Level: Dikmen Yıldizı Example

\section{Hivren DEMIR ATAY}

Tekerlerden Tekrarlara Gamba'da Dönüş ve Dönüşüm

From Bicycles to Cycles: Return and Transformation in Gamba

\section{Selma GÜNAYDIN}

Edebî Bir Siyer Örneği Olarak Çöle İnen Nư'un Kaynakları

Roots of Çöle İnen Nur As a Literary Example of Siyar

\section{Mustafa GÜNDÜZ}

Türk Eğitim Sisteminde Aşırı Militarist Uygulamanın Başlaması (1926-1947)

Starting Excessive Militarism in The Turkish Educational System (1926-1947)

\section{Nagihan GÜR}

Edebiyat Tarihi Yazımında Bir Kaynak Olarak Takrizler ve Sıra Dışı İki Örnek

Takriz Texts as a Source of Literary History Writing and Two Unusual Examples

\section{Osman ÖZEN - Kemalettin KUZUCU}

Türk Basın Tarihinde Artin Asaduryan Matbaası ve Matbaada Basılan Süreli Yayınlar ..... 117-138 Periodical Publishing Works and Artin Asaduryan Press in Turkish Press History

Yayın İlkeleri.

Editorial Principles 


\title{
Türk Basın Tarihinde Artin Asaduryan Matbaası ve Matbaada Basılan Süreli Yayınlar
}

\author{
OSMAN ÖZEN* - KEMALETTIN KUZUCU**
}

\begin{abstract}
ÖZ
Türk tarihinin en çalkantılı dönemlerinden birisini oluşturan İkinci Meşrutiyet dönemi, matbuattaki hareketlilik bakımından da dikkat çekicidir. Anayasanın getirdiği basın özgürlüğünden faydalanan Müslüman, gayrimüslim ve yabancı yüzlerce basın mensubu imtiyaz alma yarışına girmiş, neticede bir yıl içerisinde üç yüzü aşkın gazete ve dergi yayın hayatına girmiştir. Bu yayınlar söz konusu dönemin politik ve sosyolojik tahlilinin daha sağlıklı yapılabilmesi için birinci elden kaynak niteliği taşıdığı gibi, kültür ve edebiyat tarihimiz için de özgün bilgiler içermektedirler. Bu yazının konusunu, Osmanlı döneminde matbaacılığın ve gazeteciliğin yerleşmesinde önemli rolleri bulunan Ermeni girişimcilerden birisi olan Artin Asaduryan'ın kültürel faaliyetleri oluşturmaktadır. Artin Asaduryan memleketi Kayseri'den göç edip İstanbul'a yerleşmiş ve geçimini sağlamak için bir matbaada dizgicilik yapmaya başlamıştır. Daha sonra Şirket-i Mürettibiye Matbaası'nı satın alarak yayımcılığa girişmiştir. Türkçe'nin dişında Rumca, Ermenice ve Avrupa dillerinde kitaplar ve yıllıklar basan Asaduryan'ın matbaasında on üç adet de süreli yayın basılmıştır. Çeşitli aralıklarla çıkan bu yayınlar politika, askerlik, millî savunma, edebiyat, ahlâk, hukuk, siyaset, kültür, düşünce, bilim ve teknik, sanat, pedagoji, mizah gibi çok geniş bir yelpazede içeriklere sahiptir. Tablo ve grafiklerle desteklenen çalışmamızda, bu yayınların kimlik bilgileri ve içerikleri alfabetik olarak tanitilacaktir.
\end{abstract}

Anahtar sözcükler: Osmanlı Devleti, Türk basın tarihi, kültür tarihi, matbaa, Artin Asaduryan

* Kütüphaneci, İstanbul Orhan Kemal İl Halk Kütüphanesi/İSTANBUL

E-posta: osmanozen20@gmail.com

* Prof. Dr., Marmara Üniversitesi, Bilgi ve Belge Yönetimi Bölümü/İSTANBUL

E-posta: kemalettin.kuzucu@marmara.edu.tr 
Y eni Çağ'ın en önemli buluşlarından birisi olan matbaanın İstanbul'da ilk olarak 1494 yılında Yahudi cemaati tarafından açıldığı bilinmektedir. II. Selim döneminde Tokatlı Abkar isimli Ermeni'nin 1567'de matbaa açmasının ardından, Rumlar da 1627'de matbaalarına kavuşmuşlardır. Türklerin matbaayla buluşması bu tarihten tam bir asır sonradır. Yirmisekiz Mehmed Çelebi'nin oğlu Said Çelebi ile ihtida ederek İbrahim Müteferrika adını alan Macar asıllı bir Müslüman'ın gayretleriyle açılan bu matbaa ilk defa 1729'da Vankulu Lügati'ni bastıktan sonra 1742'ye kadar toplam 17 eser neşretmiştir (Birinci 2006: 293). Türk matbaacılığı, asıl 19. yüzyılda gelişmiştir. Tanzimat'la birlikte gazete ve dergi yayımcilı̆ının artması, kitap basımının yaygınlaşmasını da beraberinde getirmiş, bilhassa 1864 tarihli Vilayet Nizamnamesi'nin ardından taşrada açılan yeni matbaalarla sayısız eser okuyucuyla buluşmuştur.

Osmanlı döneminde matbaacılık sektöründe Ermeni cemaatinin yeri önemlidir. Ermeniler matbaa kurmalarının yanı sıra, mürettiplik, mücellitlik ve muharrirlik gibi görevlerle imparatorluğun yıkılışına kadar Türk basınının oluşumuna ve gelişimine katkıda bulunmuşlardır. Maarif Nezareti'nin 1899 istatistiğine göre, İstanbul'da faaliyet gösteren 90 matbaanın 32'sinin yani üçte birinin Ermenilere ait olduğu dikkate alındığında, bunların sektör içerisindeki yerleri daha iyi anlaş1lır. Belirtilen tarihte matbaalardan 23 'ünün sahibi Türk, 15'inin Rum, 5'inin Yahudi, 5'inin levanten veya Avrupalı, 2'sinin İranlı, 1'inin de Bulgar'd1 (Yarman 2001: 60). Ermeni matbaaciların önde gelen isimlerinden birisi de Artin Asaduryan'dır. Basmış olduğu eser sayısı bakımından Türk basın tarihinin en büyük beş matbaası içerisinde yer almasına rağmen Asaduryan Matbaası, gerek Osmanlı gerekse Cumhuriyet döneminde konu ile ilgili yapılan araştırmalarda -şaşılacak biçimde- gözden kaçmıştır.

\section{Artin Asaduryan'ın Hayatı ve Matbaası}

Aslen Kayserili olan Artin (Harutyan) Asaduryan; Teotig'e göre 1851'de (2012: 144), Koçu (1959: 1087), Akçura (2012: 142) ve Kevorkciyan'a (2003: 42) göre 1853 'te doğmuştur. Kayseri'de eğitimini tamamladıktan sonra genç yaşta İstanbul'a gelerek mürettiplik vazifesiyle matbaacilığa adım atmıştır. Artin Asaduryan 1880'lerin sonunda Şirket-i Mürettibiye Matbaası'nı satın aldı. Kuruluşun adını A. Asaduryan Şirket-i Mürettibiye Matbaası'na dönüştürerek yayın faaliyetlerine devam etti. Matbaaların çoğu gibi Artin'in matbaası da Bâbıâli Caddesi'ndeydi. Reşid Efendi Hanı'nda 52 numarada faaliyet yürüten matbaada hem hurufat hem de litografya baskı yapılabilmekteydi. Matbaada levhalar, tiyatro afişleri, taş basması kitaplar, hatta aynı taş üzerinde örnekleri teksir ederek cetvel işleri, muhasebe defterleri gibi evrak- 
lar da basılmaktaydı. Çıkardığı ürünlerin kalitesiyle kısa sürede göz dolduran Asaduryan matbaasının tüm çalışanları Ermeni idi (Akçura 2012: 142, Şenkartal 1987: 54). Dönemin salnamelerinde matbaanın kuruluş tarihi 1302 (1884-1885) olarak gösterilmekte ve Türkçe, Fransızca, Almanca, İngilizce, İtalyanca, Rumca, Rusça, Ermenice olmak üzere sekiz dilde baskı yapabilecek durumda bulunduğu belirtilmektedir (SNMU 1316: 756-757; SNMU 1317: 850-851; SNMU 1318: 922-923; SNMU 1319: 260-261; SNMU 1321: 266-267; Galitekin 2003: 974-975; Safi 2001: 55).

A. Asaduryan Şirket-i Mürettibiye Matbaası 1894 yılına kadar bu isimle faaliyetini sürdürdü. Fakat devletin "şirket" kelimesini iş yerlerinde kullanılmasını yasaklaması üzerine 1894 yılında işletmenin adı "Artin Asaduryan ve Mahdumları Matbaası"na çevrildi (Koçu 1959: 1087; Pamukciyan 2003: 42; Schick 2009: 60). Bu matbaa, Mahmud Bey ve Ahmet İhsan matbaalariyla birlikte otuz üç yıllık II. Abdülhamid devrinin en etkin basımevlerinden birisi olmuştur (Straus 1993: 12).

Matbaanın adından da anlaşılacağı üzere Artin Asaduryan evliydi ve sayıs1$\mathrm{n} 1$ tespit edemediğimiz erkek çocukları vardı. Asaduryan ailesi 1895 y1lında Üsküdar'da Arapzade Mahallesi'nde 2 numaralı hanede ikamet etmekteydi (BOA, DH. MKT, nr. 359/20). Artin Asaduryan Dâhiliye Nezareti'nin yayımladığı Ermeni komitelerinin kapatılması, belgelerine el konulması, örgüt liderleri ile zararlı faaliyetleri bilinen elebaşlarının tutuklanması yönündeki 24 Nisan 1915 tarihli genelge üzerine, aralarında milletvekili, yazar ve gazetecilerin de bulunduğu 235 komite mensubu ile birlikte tutuklanarak Ayaş'a gönderildi. Ayaş Hapishanesi'nde iki ay kalan Asaduryan, Dâhiliye Nezareti'nin 27 Haziran 1915 tarihli telgraf emriyle serbest birakıldı (İzrail 2013: 317). Asaduryan matbaası harf inkılabından sonra Şirketi Mürettibiye Basımevi ismi ile faaliyetini sürdürmüştür. 1934 tarihli Belediye Şehir Rehberi'ne göre, matbaa Şirket-i Mürettibiye Basımevi adı ile 73 numarada yer almaktadır. Aynı rehberde ayrıca matbaanın 1908 tarihinde Artin Asaduryan'ın oğlu Ardaş Asaduryan'a intikal ettiği de belirtilmektedir (Koçu 1959: 869; 2007: 94). Matbaa 1955-1956 y1lına ait İstanbul Telefon Rebberinde görülmektedir (İstanbul Telefon Rehberi 1955-1956: 64).

19. yüzyılda Türkçe edebî eser yayımcilı̆̆ı üzerine yapılan bir çalışmada Artin Asaduryan'ın matbaası, 1863-1900 döneminde yaptığı 567 baskıyla İstanbul'da Türkçe eser basan matbaalar sıralamasında dördüncü sıradadır (Ayaydın Cebe 2009: 300). Aynı dönemde 177 baskıyla edebiyat alanında en çok eser veren matbaalar sıralamasında yedinci sırada gösterilmiştir (Ayaydın Cebe 2009: 312; İzrail 2013: 317). Tespitlerimize göre matbaa, 18891900 tarihleri arasında 511, 1901-1907 tarihleri arasında 167 eser basmıştır. 
Schick ise matbaanın 1908-1912 y1lları arasında 221 kitap basmak suretiyle ülke çapında en çok yayın yapan üçüncü matbaa sırasına girdiğini belirtmektedir (Schick 2009: 60; Akçura 2012: 142). Matbaada 1908-1912 yıllar1 arasında eser 282 adet, 1913-1928 yılları arasında 456 adet eser basılmıştır. Artin Asaduryan 1889-1928 yılları arasında toplamda 1417 eser olmak üzere yıllık ortama 36 adet eser basmıştır. Grafik I'de 1889 yılından başlayarak Harf İnkılâbı'na kadar geçen süreçte Artin Asaduryan'ın matbaasında Arap harfleriyle basılmış Türkçe 1417 eserin yıllara göre dağılımı görülmektedir. Grafiğe Arap alfabesiyle Türkçe basılmış eserler ve nevsâller (yıllıklar) ile niteliği itibarıyla Türkçe ve diğer dillerde yazılmış olan lügatler dâhil edilirken, gazete ve dergi gibi süreli yayınlar değerlendirme dışı bırakılmıştır. Matbaada en fazla eser 1912 yılında 75 adet, en az eser 1906 yilında 6 adet eser basilmıştır. Yayın adedinin yıllara göre dağılımında bir istikrar bulunmayıp, inişli çıkışlı bir grafik seyretmiştir. Bu durum matbaanın ekonomik yapısıyla ve devletin yayım faaliyetleri üzerindeki kontrolüyle izah edilebilir. Öte yandan Asaduryan'ın bastığı kitapların isimlerinin dökümü bu çalışmanın kapsamını aştığından bununla ilgili bir çalışmaya girişilmemiştir.

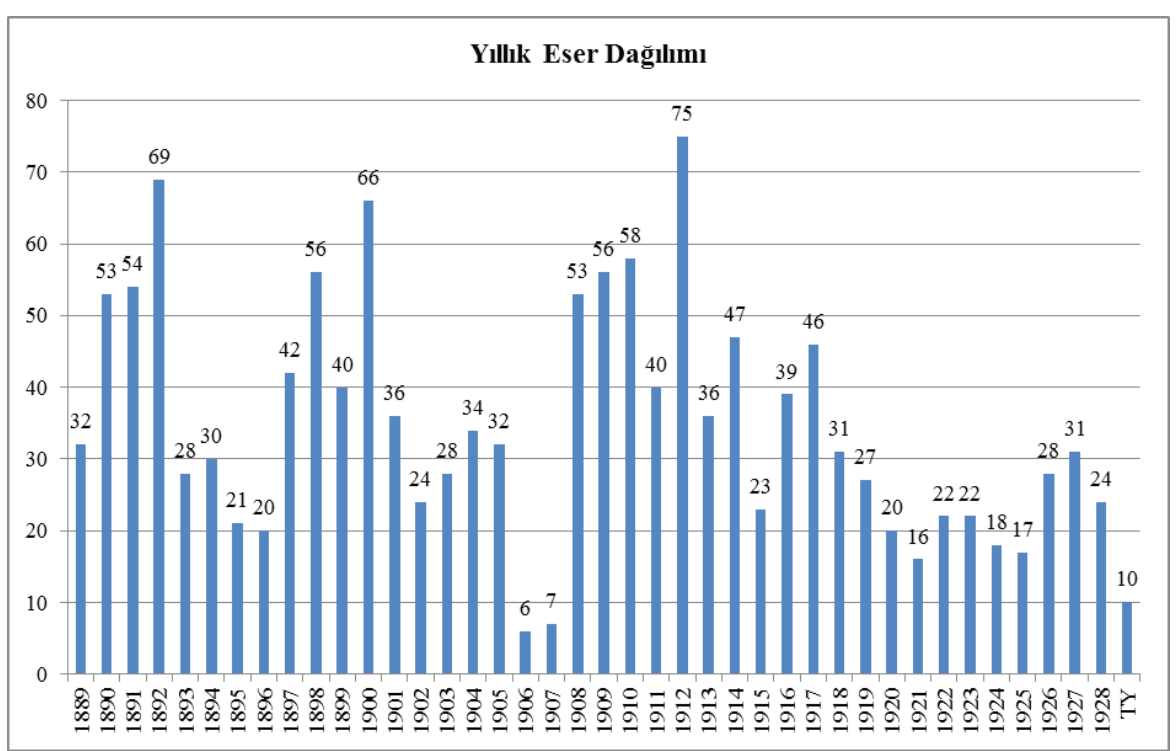

Grafik I: Artin Asaduryan’ın Bastığı Eserlerin Yıllara Göre Dağılımı1

1 Grafik hazırlanırken; M. Seyfettin Özege, Eski Harflerle Basılmış Türkçe Eserler Kataloğu, c. 1 s. 1-428, Fatih Yayınevi Matbaası, İstanbul 1971; M. Seyfettin Özege, Eski Harflerle Basılmış Türkçe Eserler Kataloğu, c. 2, s. 437-952, İstanbul 1973; M. Seyfettin Özege, Eski Harflerle Basılmış Türkçe Eserler Kataloğu, c. 3, s. 957-1422, İstanbul 1975; M. Seyfettin Özege, Eski Harflerle Basılmış Türkçe Eserler Kataloğu, 


\section{Artin Asaduryan'ın Basmış Olduğu Süreli Yayınlar}

Süreli yayın anlayı̧̧ı Gutenberg'in modern anlamdaki ilk baskı makinesini bulmasından yaklaşık iki yüzyıl sonra ortaya çıkmıştı. İlk olarak 17. yüzyı1da görülen bu yayınlar, gayriresmi haber ve dedikodu bültenleri niteliğindeydi. Avrupa'dan başlayarak dalga dalga bütün dünyayı sarmaya başlayan süreli yayınlar ilk olarak 1563'te İtalyada yayımlanmış, bunu Fransa (1605), İsviçre (1600), Avusturya (1610), Almanya (1612), İngiltere (1622), İspanya (1626) ve Rusya'dakiler (1703) takip etmiştir (Mildanoğlu 2014: 9). Osmanlı İmparatorluğu'nda gazeteyi devletten ve devletin kendi tebaasından önce yabancılar çıkarmışlardır. Fransa'nın İstanbul'daki olağanüstü elçisi Verninac'in 1795'te yayımladığı Bulletin de Nouvelles adlı gazete, imparatorluk sinırlar1 içerisinde çıkarılan ilk süreli yayın olarak bilinmektedir. 1824'ten itibaren İzmir'de Smyrnéen, Spectateur Oriental ve Courrier de Smyrne adlı özel gazeteler yayımlanmaya başlar. Bunları İstanbul ve diğer şehirlerdeki diğer özel gazeteler takip eder (Alemdar 1980: 2-4). Bu arada Kavalalı Mehmed Ali Paşa, idaresi altına aldığı Mısır'da birçok yenilik kapsamında Vekâyi'i $i$ Mısriyye adl 1 yarı Arapça yarı Türkçe bir gazeteyi 1828'de yayımlamaya muvaffak olur (Yazıcı 1991: 268). Osmanlı Devleti'ndeki ilk Türkçe gazete ise 1 Kasım 1831 tarihinde yayımlanmaya başlayan Takvîm-i Vekâyi’dir. ${ }^{2}$ Özel gazetelerin birincisi olan 1840 tarihli Cerîde-i Havâdis'in ardından, İstanbul'da ve taşrada onlarca süreli yayın çıkarılmaya başlanmış, II. Meşrutiyet'in ilanıyla birlikte aralarında mizah dergilerinin de bulunduğu edebiyat, bilim, teknik ve politika içerikli sayısız neşriyat yapılmıştır. Bu dönemin süreli yayın neşriyatının önde gelen isimlerinden birisi de Artin Asaduryan'ır. Tespitlerimize göre Asaduryan'ın bastığı süreli yayınların sayısı 13'ü bulmaktadır ve bunların çoğu dergi niteliğindedir. Aşağıda ağırlıklı olarak Artin Asaduryan Matbaası'nda basılan süreli yayınlar alfabetik olarak kısaca tanıtılmıştır.

c. 4, s. 1429-1942, İstanbul 1977; Nuri Akbayar, Eski Harflerle Basılmış Türkçe Eserler Kataloğu'na Zeylü'z-Zeyl, Müteferrika 1 (1993), s. 45-50; Nuri Akbayar, Eski Harflerle Basılmış Türkçe Eserler Kataloğu'na Zeylü'z-Zeyl (II), Müteferrika 2 (1994), s. 95-101; Nuri Akbayar, Eski Harflerle Basılmış Türkçe Eserler Kataloğu'na Zeylü'z-Zeyl (III), Müteferrika 3 (1994), s. 93-98; Nuri Akbayar, Eski Harflerle Basılmış Türkçe Eserler Kataloğu'na Zeylü'z-Zeyl (IV), Müteferrika 15 (1999), s. 75-85; Nuri Akbayar, Eski Harflerle Basılmış Türkçe Eserler Kataloğu’na Zeylü’z-Zeyl (V), Müteferrika 19 (2001), s. 59-71, Nuri Akbayar, Eski Harflerle Basılmış Türkçe Eserler Kataloğu'na Zeylü'z-Zeyl (VI), Müteferrika 50 (2016), s.179-193; Erzurum Atatürk Üniversitesi Kütüphanesi, İstanbul Büyükşehir Belediyesi Atatürk Kitaplığı, Ankara Milli Kütüphane, İstanbul Millet Kütüphanesi, Marmara Üniversitesi Kütüphanesi, Türkiye Diyanet Vakfı İslam Araştırmaları Kütüphanesi (İSAM) ve Çamlıca Araştırma Merkezi Kütüphanesi'nin çevrimiçi katalogları ile Kudret Emiroğlu ve İlker Mustafa İşoğlu tarafindan Milli Kütüphane için hazırlanan Eski Harfli Türkçe Basma Eserler Bibliyografyası (Ankara 2001) adlı CD'den yararlanılmıştır.

2 Takvîm-i Vekâyi hakkında bkz. Nesimi, Yazıcı (1983). Takvîm-i Vekâyi, Ankara: Gazi Üniversitesi Basın Yayın Yüksekokulu Yayını. 


\section{Asker}

Derginin ilk sayısı 21 Ağustos 1324 (3 Eylül 1908) tarihinde 48 sayfa olarak çıkmış olmakla birlikte, kuruluş tarihi sembolik olarak "11 Temmuz 1324 yevm-i mes ûdu”na, yani II. Meşrutiyet'in ilan edildiği 24 Temmuz 1908 tarihine denk düşürülmüştür. "Ordu ve donanmanın terakkiyatına hâdim olmak üzere ayda iki defa neşredilir" ibaresinden anlaşılacağı üzere on beş günde bir yayımlanan dergi 1326 yılında 29. sayı ile yayın hayatına son vermiştir (Duman 2000: 148). Son sayı üzerinde gün ve ay belirtilmemiştir. Derginin kurucusu ve başyazarı Erkân-1 Harbiye kaymakamlarından Osman Senaî [Erdemgil], yayın müdürü İbnüssırrı Ahmed Cevdet'tir (Asker, nr. 1). Askerler tarafından çıkarılan en dikkate değer dergilerden birisi olan (Birinci 1995: 195) Asker, muharebe talimleri ve bazı askerî gelişmeler ile yabancı devletlerin askerî yapıları ve sistemleri hakkında yazılar içermektedir (Pehlivanlı 2005: 253). Derginin birinci sayısı Asaduryan'ın Şirket-i Mürettibiye Matbaası'nda (Asker, nr. 1), ikinci sayı Mahmud Bey Matbaası'nda (Asker, nr. 2) üçüncü sayı ise Hilal Matbaası'nda (Asker, nr. 3) basılmış olup diğer sayılarda ise matbaa ismine rastlanmamıştır.

\section{Aşiyan}

"Edebî, ilmî, ahlakî haftalık mecmuadır" ibaresiyle 28 Ağustos 1324 (10 Eylül 1908) tarihinde yayımlanmaya başlamış, 26. sayı ile 26 Şubat 1324 (12 Mart 1910) tarihinde yayın hayatına sona vermiştir. Derginin kurucusu İbnüssırrı Mustafa Namık (Çankı), müdürü ise İbnüssırrı Ahmed Cevdet'tir (Aşiyan, nr. 1). A. Birinci, derginin imtiyaz sahibinin Mustafa Namık'ın babası ve Zonguldak'ın eski nâiblerinden S. Sırrı Bey olduğunu belirtmektedir. Fark$l_{1}$ ülkelerin edebiyatlarından yapılmış çevirilerle dikkati çeken dergide, şiir, tiyatro ve piyes metinlerine de yer verilmiştir (1995: 146). Tevfik Fikret'ten İsmail Safaya, Hüseyin Cahid'den Süleyman Fehmi'ye kadar çok geniş bir şair ve yazar kadrosuna sahip olan Aşiyan, okurlarına Mâzi ve Âti adlı bir de ek armağan etmiştir. Birinci sayısı Şirket-i Mürettibiye Matbaası'nda yayımlanan Aşiyân'ın 2., 3., 4., 5., 6. ve 7. sayıları Matbaa-i Amire'de, (Aşiyan, nr. 2) 8., 9. ve 10. sayıları Selanik Matbaası'nda (Aşiyan, nr. 8), 11. sayı Şirket-i Mürettibiye Matbaası'nda (Aşiyan, nr. 11) , 12., 13., 14. ve 15. sayıları Artin Asaduryan Matbaası'nda (Aşiyan, nr. 12), 16. sayı ve 17. sayı Matbaa-i Ahmed İhsan'da (Aşiyan, nr. 16), 18. sayı Merkez Matbaa'da (Aşiyan, nr. 18), 19. sayıdan son sayı olan 26. sayıya kadar Matbaa-i Hayriye ve Şirketi'nde (Aşiyan, nr. 19) basılmıştır. 


\section{Cerîde}

2 Teşrinievvel 1324 (16 Ekim 1908) tarihinde yayımlanmaya başlayan Cerîde, 48. sayı ile 6 Ağustos 1325 (18 Ağustos 1909) tarihinde yayın hayatı sona ermiştir (Akdemir Örnekkol 2014: 6-7). Yayının sahibi ve başmuharriri Mahmud Celaleddin, yazı işleri müdürü ise Hasan Bedri Paşa idi (Ebüzziya 1993: 403). Haftada bir perşembe günleri yayımlanan Cerîde kendisini "edebî ve siyasî gazete" olarak tanımlamı̧, kenarları desenli kaligrafik dikdörtgen içerisindeki kimliğinin üç tarafına "adalet", "hürriyet" ve "müsavât" kavramlarını yerleştirmişti. Kapakta dikkat çeken bilgilerden birisi de gazetenin idare merkezi adresi olarak Artin Asaduryan Matbaası'nın üst katının gösterilmesidir (Cerîde, nr. 1). 28 Zilhicce 1326 (21 Ocak 1909) tarihli 15. sayıda gazetenin idarehanesinin, değiştiği ve "Bâbıâli Caddesi’nde Meserret Oteli karşısında 24 numero"ya (Cerîde, nr. 15) yerleştiği kaydedilmiştir. 1. sayıdan (Cerîde, nr. 1) 14. sayıya kadar Artin Asaduryan Matbaası'nda, 17. sayı (Cerîde, nr. 17), 19. sayıdan 33. sayıya, 41. sayıdan (Cerîde, nr. 41) 48. sayıya kadar Asaduryan Matbaasında, 15. sayı ve 16. sayı ile 34. sayıdan (Cerîde, nr. 34) 40. sayıya kadar Uhuvvet Matbaası'nda basılmıştır. 18. sayının üzerinde ise matbaa bilgisi bulunmamaktadır (Cerîde, nr. 18).

\section{Ceride-i Baytariye ve Ziraiye}

Ceride-i Baytariye ve Ziraiye 1 Teşrinisani 1315 (13 Kasım 1899)- 22 Temmuz 1320 (4 Ağustos 1904) tarihleri arasında on beş günlük ve haftalık olarak beş sene çıkarılmıştır. Mecmuanın sahibi Mehmed Kemal, müdürü ve sermuharriri A. N. İsmet, müdürü F. Ali'dir. Birinci sayısında ayda iki defa "menâfi-i mülk-ü devlete hâdim ibaresi” ile çıkmıştır (Ceride-i Baytariye ve Ziraiye, birinci sene, nr. 1). Mecmua hayvancilık ve ziraat alanında önemli bilgiler içermektedir. Ceride-i Baytariye ve Ziraiye birinci sene 24 sayı, ikinci sene 2 sayı, üçüncü sene 49 sayı, dördüncü sene 44 sayı, beşinci sene 20 sayı olmak üzere toplam 139 sayı ç1karılmıştır. Yıllara göre yayının kapak sayfasının tasarımı değişiklik göstermiştir. Mecmuanın sayıları ilerledikçe resimler artmış olup ağırlıklı olarak hayvancılık ve ziraat alanı ile ilgili resimler bulunmaktadır. Ceride-i Baytariye ve Ziraiye'nin birinci senenin 1. ve 2. sayıları Ahter Matbaası'nda (Ceride-i Baytariye ve Ziraiye, birinci sene, nr. 1), 5. ve 6. sayıları, 9. ve 10. sayıları, 16. ve 17. sayıları Artin Asaduryan Şirket-i Mürettibiye Matbaası'nda (Ceride-i Baytariye ve Ziraiye, birinci sene, nr. 5), 7. ve 8. sayıları, 18. sayıdan 24. sayıya kadarki sayılar ile ikinci sene 1. ve 2. sayılar Mektebi Sanayi-i Şahane Matbaası'nda (Ceride-i Baytariye ve Ziraiye, birinci sene, nr. 7; ikinci sene, nr. 1) üçüncü senenin ilk sayısı Karabet Matbaası'nda (Ceride-i Baytariye ve Ziraiye, üçüncü sene, nr. 1) di- 
ğer sayıların hepsi, dördüncü senenin bütün sayıları, beşinci senenin ilk on sayısı Hanımlara Mahsus Gazete Matbaası'nda (Ceride-i Baytariye ve Ziraiye, dördüncü sene, nr.1; beşinci sene, nr. 1) son on sayısı ise Mahmud Bey Matbaası'nda (Ceride-i Baytariye ve Ziraiye, beşinci sene, nr. 11) basılmıştır.

\section{İstişare}

İstişare, Bâbıâli İstişâre Odası muavinlerinden Suad Muhtar tarafından kurulmuş, Mehmed Sâlih ise sorumlu müdürlüğünü ve başyazarlığını üstlenmiştir. Yayın aralığını ve politikasını "Haftada bir defa neşr olunur hukuk ve siyasiyâttan bâhis ilmî, edebî mecmuadır" şeklinde ifade eden İstişare 4 Eylül 1324 (17 Eylül 1908) tarihinde yayımlanmaya başlamış, 19 Mart 1324 (1 Nisan 1909) tarihinde çıkan 27. sayı ile yayın hayatına son vermiştir. Cerîde gibi bunun idarehanesi de Asaduryan Matbaası'nın üst katıydı. 48 sayfa çıkan derginin ilk sayısında Meşrutiyet düşüncesini yerleştirmek uğrunda siyasî tarih ile hukuk tarihini mezcederek hukuk alanında ihtiyaç duyulan boşluğu doldurmaya gayret edileceği ve bu alanda yapılacak inkılap hakkında fikir üretileceği ifade edilmiştir. Bunun yanında siyasî, ilmî ve edebî yazılara da yer verileceği belirtilmiştir. Bu kapsamda Ahmed İhsan'ın "Hâkimiyet-i Milliye" 124 başlıklı yazısı anılabilir (İstişâre, nr. 1). İstişare Artin Asaduryan Matbaası'nda basılmıştır.

\section{Malumat}

Mehmed Fuad ile Artin Asaduryan'ın birlikte çıkardıkları dergi 10 Şubat 1309 (22 Şubat 1894) tarihinde yayın hayatına başladı. Yazı işleri Mehmed Fuad'ın, idari konular Artin'in sorumluluğundaydı. "Perşembe günleri neşrolunur edebî, fennî, sınâî gazetedir” sloganıyla çıkan derginin idarehanesi Babıali Caddesinde 52 numaralı Şirket-i Mürettibiye Matbaası'ydı (Malumât, nr. 1). Çeşitli nedenlerden dolayı birkaç hafta çıkamamış olan Malumât 20 Nisan 1311 (2 Mayıs 1894) tarihli 48. sayısında yayınına son verme kararı almıştır. Bunun sebebini de, derginin nail olduğu rağbet karşısında kendisini yenilemesi, sayfa sayısının arttırılması ve görsel malzemeler yayımlanması gibi bazı zorunlu iyileştirmelerle okuyucunun karşısına daha göz doldurucu bir şekilde çıkmak olarak izah etmiştir. Dergi, daha sonra Baba Tahir olarak şöhret bulacak olan Mehmed Tahir'e devredilmiştir (Malumat, nr. 48). Malumat' ın yazı kadrosunda, Muallim Feyzî, Hüseyin Dâniş ve Müstecabîzâde İsmet Bey gibi eski tarzda şiirler yazan şairlerin yanı sıra, başta Tevfik Fikret olmak üzere İsmail Safâ, Süleyman Nazif, Hüseyin Sîret, Abdullah Cevdet gibi genç isimler de yer almaktaydı. Bu nedenle bir süre sonra Servet-i Fünûn dergisi çevresinde Edebiyat-1 Cedîde topluluğunu meydana getirecek olan devrin bir 
kısım genç edebiyatçılarının bir araya gelip faaliyet göstermeye başladıkları ilk yayın olması bakımından Malumât' 'n Türk edebiyatı tarihinde önemli bir yeri vardır (Uçman 2003: 542).

\section{Malumat}

Malumat, Baba Tahir adıyla tanınan Mehmet Tahir tarafindan 11 Mayıs 1311 (23 Mayıs 1895) (Malumat, nr. 1) - 7 Ağustos 1319 (20 Ağustos 1903) tarihleri arasında 423 sayı çıkarılmış olup sekiz yayın hayatında kalmışıı (Uçman 2003: 543; Bal 2007: 38). Malûmat kendisini ilk sayıdan 29. sayıya kadar "Menâfi-i mülk-i devlete hâdim haftalık musavver Türk gazetesidir" şeklinde tanıtmıştır (Malumat, nr. 1; Bal 2007: 38). 31. sayıdan itibaren "Devlet ve memleketin menafi'ne hizmet eder ve haftada bir defa perşembe günleri musavver olarak neşr olunur" ibaresi yer almıştır (Malumat, nr. 31-32; Bal 2007: 41). İbareden anlaşıldığına göre dergi haftalık olarak genellikle perşembe günleri çıkmıştır. Malûmat, askerlik, ahlak, sanat, fen, hukuk, musiki, felsefe, psikoloji, eğitim, spor, tarım gibi alanlarda kitlesine hitap etmiştir. Malûmat İstanbul dışındaki taşra ve yurt dışında da abonelere sahiptir (Bal 2007: 47).

Malumat edebi, fenni, siyasi bir mecmuadır. Malumat'ın en önemli özelliği kapak sayfasında ve içerisinde çok fazla fotoğraf ve resim kullanmasıdır. Bundan dolayı Mussaver Malumat adı ile de tanınmıştır. Mecmuada yayınlanan fotoğraflar dönemin önemli unsurları içermektedir. Bunlar; dönemin paşaları, kasaba, şehir, rıhtım, iskele, okul, cami, gemi, savaş topları bazen tarihi mekânlar bazen de şehirlerde yer alan önemli devlet dairelerinin diğer unsurlar ile ilgili birçok fotoğraf bulunmaktadır. Fotoğrafın kime ya da nereye ait olduğu, fotoğrafın hemen altında Türkçe, Arapça ve Fransızca olarak açıklanmıştır (Bal 2007: 43-44). Bu durum mecmuanın farklı dillerdeki kitleyi hitap edebildiğini göstermektedir.

Malumat' 1 alt başlĭğ Fransızca olarak Illustration Turque Malumat'tır. 59. nüshadan itibaren Illustration Turque Malumat ibaresinin hemen üstünde "Ümmet-i celîle-i islâmiye ve millet-i necîbe-i Osmaniye'nin her veçhile menâfi'ne hâdim âsâr-1 kalemiyeye sahâif Malûmat her zaman küşâdedir" ifadesi yer almaktadır (Malumat, nr. 59). 1. sayıdan 81. sayıya kadar $M a-$ lumat "Matbaa ve idarehanesi: Bab-1 âlî Caddesi'nde 52 numaralı dairedir. Umûr-1 idare ve tahririyeye müteallik her nevi husûsat için müdür ve muharrir Mehmet Tahir Bey'e müracaat olunur" (Malumat, nr. 1; Malumat, nr. 81; Bal 2007: 39-40) şeklinde yazmaktadır. Matbaanın 52 numaralı daire olduğunun belirtilmesi Artin Asaduryan matbaası olduğunu göstermektedir. İlk seksen bir sayı Artin Asaduryan Matbaası'nda basılmıştır. Diğer 82-423 arası sayllılar ise "Matbaa ve idarehanesi: Bab-1 âlî Caddesi'nde 40 numaralı dairedir” (Malumat, nr. 82) olduğu belirtilmiştir. 


\section{Mecmua-i Fünûn-i Baytariye}

Mecmua-i Fünûn-i Baytariye, 1 Eylül 1324 (14 Eylül 1908) tarihinde yayın hayatına başlamıştır. Birinci sene 16, ikinci sene 8 sayı olmak üzere toplam 24 sayı yayımlanmıştır. Son sayı Nisan 1326 (Nisan 1910) tarihinde çıkarılmı̧tır. Mecmua-i Fünûn-i Baytariye başlangıçta on beş günlük olarak çıkarılmaya başlamıştır. Ancak 1 Mart 1325 (14 Mart 1909) tarihli 13. sayıdan itibaren aylık yayımlanmış ve son sayısına kadar bu düzeni korumuştur. Derginin çıkış amacı ilk sayıdaki "Mecmua-i Fünûn-i Baytariye'nin Mesleğì" başlıklı makaleye göre, dönemin siyasî, ekonomik ve askerî dinamiklerini belirleyen hayvan hastalıkları ile mücadelede etkin rol oynamak olarak belirtilmiştir. Meстиa-i Fünûn-i Baytariye’nin başyazarlığını Osman Nuri (Eralp) Bey yapmıştır. Mecmuanın müdürü ise Osmanlı Cemiyet-i İlmiyye-i Baytariyesi Müessis ve Reisi ve Mülkiye Baytar Mekteb-i Âlisi Müdürü Mehmet Ali Bey'dir (Melikoğlu Gölcü ve Osmanağaoğlu Sanal 2012: 48, 50-51). Мeстиa-i Fünûn-i Baytariye'nin 1. sayı Mekteb-i Tibbiye-i Askeriye Matbaası'nda (Mecmua-i Fünûn-i Baytariye, Birinci sene, nr. 1), 2. sayıdan (Mecmua-i Fünûn-i Baytariye, Birinci sene, nr. 2) 4. sayıya kadar Mekteb-i Tibbiye-i Askeriyeyi-i Şahane Matbaası'nda, 5. sayıdan 9. sayıya kadar Mekteb-i Tıbbiye-i Osmaniye Matbaası'nda (Mecmua-i Fünûn-i Baytariye, Birinci sene, nr. 5), 10. sayıdan 15. sayıya kadar Mekteb-i Tibbiye-i Şahane Matbaası'nda (Mecmua-i Fünûn-i Baytariye, Birinci sene, nr. 10), ikinci sene 1 ve 2. sayılar Artin Asaduryan ve Mahdumları Matbaası'nda (Mecmua-i Fünûn-i Baytariye, İkinci sene, nr. 1), ikinci sene 5 ve 7. sayılar Mekteb-i Sanayi-i Matbaası'nda (Mecmua-i Fünûn-i Baytariye, İkinci sene, nr. 5), basılmıştır.

\section{Mektebli}

Mektebli 16 Mayıs 1329 (30 Mayıs 1913) - 10 Nisan 1330 (23 Nisan 1914) tarihleri arasında 39 sayı yayımlanmıştır. Mektebli'nin sahibi ve kurucusu Mağmûmî'dir. Başyazarı Emin Hâkî, sorumlu müdürü Hüseyin Hâmid idi. Genelde haftanın Perşembe günü yayımlanan Mektebli, sayfa tasarımı ve yayın anlayışı bakımından dönemindeki birçok yayından farklılık gösterir. "Zükûr ve inâs bilumum rüşî̀ ve idâdî müdaviminin tenvîr-i efkâr ve hissiyatına hâdim; ilmî, fennî, edebî, sınâî musavver haftalık mecmuadır" sunumuyla çıkan derginin hedef kitlesi ortaöğretim öğrencileriydi. "Mesleğimize muvâfik ve açık Türkçe yazılmış âsâra sahifelerimiz açıktır" diyerek hem tarafsızl1ğını ortaya koymuş hem gençleri yazmaya ve araştırmaya teşvik etmiş hem de gönderilecek yazıların yayımlanma ölçütünü kesin bir dille ifade etmiştir. Öğrencilerin yazıları için iki sahife tahsis edildiği belirtilmiştir (Mektebli, nr. 1). Derginin bir özelliği de yer yer resimler ve sayfalarca reklam yayımlamı̧̧ 
olmasıdır. Mektebli 20. sayıdan itibaren İskender Fahreddin’e devredilmiştir. Yazar kadrosunda Tahirül Mevlevi, Abdullah Cevdet, Lord İsmail, Yaşar Nezihe ve Süleyman Şemseddin gibi kalemler bulunmaktaydı (Deniz 2010: 21-22). İlk on sayısı Artin Asaduryan ve Mahdumları Matbaası'nda basılan derginin müteakip sayıları Resimli Kitab Matbaası, İttihad Ticaret Kütüphanesi, Nefaset Matbaası, Selanik Matbaası, Hilal Matbaası ve Mahmud Bey Matbaası'nda basılmıştır.

\section{Musavver Karnaval}

Meşrutiyet döneminde basının patlama yapmasına rağmen Musavver Karnaval ancak tek sayı yayımlanmaktan öteye gitmeyen mizah dergilerinin tipik örneklerinden birisidir. Abdülkadir tarafindan 9 Eylül 1324 (12 Eylül 1908) tarihinde "Şahsiyâtdân 'ârî mudhik ve güzel hikâyeler, musâhabeler ma'a'1memnûyiyye kabul ve derc olunur" şeklindeki ölçüt ve vaat ile yayımlanan dergide bir karikatür ile "Abduş" ve "Görmüş Geçirmiş" gibi müstear isimlerin yazılarına yer verilmiştir (Musavver Karnaval, nr. 1). Süreli yayın kataloglarında Karnaval ve Musavver Karnaval şeklinde kaydedilmiş olan derginin sahibinin Enver olduğu belirtilmiştir (Duman 1986: 285; Eski Harfli Türkçe Süreli Yayınlar Toplu Kataloğu 1987: 182; Duman 2000: 613). Tek sayı ç1karılan Musavver Karnaval Artin Asaduryan Matbaası'nda basılmıştır (Musavver Karnaval, nr. 1).

\section{Necm-i Terakki}

İmtiyaz sahibi, Üsküdar'da ibtidâî ve rüşdiye düzeyinde eğitim veren Necm-i Terakki Mektebi'nin kurucusu ve müdürü Hüseyin Hıfzı'dır. Aynı zamanda yazar olan ve okul bünyesinde kurduğu Necm-i Terakki Kütüphanesi adlı yayıneviyle sayısız eser yayımlayan (İgüs 2008: 91) Hüseyin Hıfzı'nın haftalık Necm-i Terakki gazetesi 8 Ağustos 1324 (21 Ağustos 1908) tarihinde yayımlanmaya başlamıştır. Yayın ilkesini "Vatan ve milletin menâfi'ine yarar her nev âsâr memnuniyetle kabul ve derç olunur" şeklinde duyuran gazete, daha hacimli çıkmak arzusunda olmasına rağmen dört sayfa yayımlanmak zorunda kalışını, basın özgürlüğünden dolayı matbaaların birden bire çoğalmasının yol açtığı kâğıt kıtlığına bağlamıştır. ${ }^{3}$ İlk sayısı Asır Matbaası'nda basılan Necm-i Terakkinin 2., 3. ve 4. sayıları Hacı Hüseyin Efendi Matbaası'nda,

3 "Matbuâtımızın otuz iki senelik şiddetli bir tazyikten kurtularak serbestîyi kemâl-i tahassürle kucakladığı şu zamanda devr-i istibdâdın zulm ve i'tisâfından harabe halinde bekâ bulabilen matbaaların kesret-i iştigaliyle kâğıdın fikdanından dolayı Necm-i Terakki arzumuz veçhile tulû‘ edemedi." (Necm-i Terakki, nr. 1, 23 Receb 1326). 
(Necm-i Terakki, nr. 2) 5. sayısı ise Artin Asaduryan Matbaası'nda bası1mıştır (Necm-i Terakki, nr. 5). Dergi 9. sayıdan itibaren bir süre Karacaoğlu Matbaası'nda (Necm-i Terakki, nr. 9) basıldıktan sonra 43. sayısında bir kez daha adres değiştirerek Necm-i İstikbâl Matbaası'na (Necm-i Terakki, nr. 49) yönelmiş ve 3 Eylül 1325 (16 Eylül 1909) tarihinde çıkan 49. ve son sayısına kadar burada basılmıştır.

\section{Vay Vay}

Cumhuriyet devrinin ilk mizah gazetelerinden birisi olan Vay Vay 21 Haziran 1341 (21 Haziran 1925) - 5 Temmuz 1341 (5 Temmuz 1925) tarihleri arasında haftalık olarak üç sayı çıkarılmıştır. Müdür-i mes'ûlü Hakkı Nezih olan (Vay Vay, nr. 1) gazete 4 sayfa olarak çıkarılmıştır. 5 Temmuz 1341 (5 Temmuz 1925) tarihinde yayın dünyasından çekilmiştir. Vay Vay Şirket-i Mürettibiye Matbaası'nda basılmıştır. Bazı kataloglarda günlük olduğu ileri sürülmüş ise de (Duman 1986: 447; Duman 2000, 921; Öztürk ve Haciismailoğlu, Hizarcı 2006: 421) bu doğru değildir. Eleştirel karikatürler, hiciv şiirleri ve mizah açısından zengin bir içeriğe sahiptir.

\section{Zafer}

Zafer'in imtiyaz sahibi ve sorumlu müdürü İsmail Hakkı'dır. Zafer 1 Mart 1328 (14 Mart 1912) tarihinde yayın hayatına başlamıştır. 12 sayfa olarak yayına başlayan gazete, "Hayat, efkâr ve terakkiyât-1 askeriyeden bâhis musavver askerî haftalık gazetedir" sloganıyla yola çıkmıştı. İlk sayısının birinci sayfasında "Müslümanların halifesi, Osmanlıların padişahı, kumandan-1 akdes ve a'zamımız sevgili Sultan Mehmed Hân-1 Hâmis efendimiz hazretleri” altyazısıyla Sultan Reşad'ın fotoğrafını yayımlamıştır (Zafer, nr. 1). Gazete 20 Eylül 1328 (3 Ekim 1912) tarihinde çıkan 28. sayı ile yayın hayatı sona ermiştir. (Zafer, nr. 28; Duman 1986: 469; Duman 2000: 961). Gazete A. Asaduryan ve Mahdumları Matbaası'nda basılmıştır. 10. sayıda matbaanın ismi Asaduryan ve Mahdumları Matbaası şeklini almıştır (Zafer, nr. 10). 11. sayıda tekrar A. Asaduryan ve Mahdumları Matbaası şeklini almıştır (Zafer, nr. 11). 26-28. sayılar ise Nefaset Matbaası'nda basılmı̧̧ır (Zafer, nr. 26). Gazete mülkî ve askerî erkânın portrelerinin yanı sıra, kışla hayatını, doğal manzarayi, resmî törenleri, kara ve deniz muharebelerini, askerî teknolojinin yeniliklerini tasvir eden fotoğraflar ve çizimlerle zengin bir görsel içerik sunar.

Tablo I'de Artin Asaduryan'ın matbaasında basılan süreli yayınların bir tablosu verilmiştir. Tabloda ilk sayının tarihi, süreli yayının sorumluları, süreli yayının adı, basıldığı matbaa, kaç sayı çıtı̆̆ı, süreli yayının süresi ve hangi 
gün çıktığı belirtilmiştir. Tabloda bulunan bazı yayınlar farklı matbaalarda da basılmış olup Artin Asaduryan matbaasında basıldığı için süreli yayınların bütün sayıları belirtilmiştir.

\begin{tabular}{|c|c|c|c|c|c|c|}
\hline İlk Sayı Tarihi & Sorumlular & Yayının Adı & Basıldığı Matbaa & Sayl & Süre & Gün \\
\hline $\begin{array}{l}21 \text { Ağustos } 1324 \\
\text { (3 Eylül 1908) }\end{array}$ & $\begin{array}{l}\text { Müessis ve başmuharriri: } \\
\text { Osman Senaî, } \\
\text { Müdürü: İbnüssırrı } \\
\text { Ahmed Cevdet }\end{array}$ & Asker & $\begin{array}{l}\text { Şirket-i Mürettibiye Matbaası, } \\
\text { Mahmut Bey Matbaası, } \\
\text { Hilal Matbaası }\end{array}$ & 29 & Ayda iki defa & \\
\hline $\begin{array}{l}28 \text { Ağustos } 1324 \\
\text { (10 Eylül 1908) }\end{array}$ & $\begin{array}{l}\text { Sahibi: Salih Sırrı, } \\
\text { Müdürü: İbnüssırrı } \\
\text { Ahmed Cevdet }\end{array}$ & Asiyan & $\begin{array}{l}\text { Şirket-i Mürettibiye Matbaası, } \\
\text { Matbaa-i Amire, Artin } \\
\text { Asaduryan Matbaası, Selanik } \\
\text { Matbaası, Matbaa-i Ahmet } \\
\text { İhsan, Merkez Matbaa, } \\
\text { Matbaa-i Hayriye ve Şirketi }\end{array}$ & 26 & Haftalık & Perşembe \\
\hline $\begin{array}{l}2 \text { Teşrinievvel } 1324 \\
\text { (16 Ekim 1908) }\end{array}$ & $\begin{array}{l}\text { Sahibi ve başmuharriri: } \\
\text { Mahmud Celaleddin, } \\
\text { Yazı İşleri Müdürü: } \\
\text { Hasan Bedri Paşa }\end{array}$ & Ceride & $\begin{array}{l}\text { Artin Asaduryan Matbaası, } \\
\text { Uhuvvet Matbaası }\end{array}$ & 48 & Haftalık & Perşembe \\
\hline $\begin{array}{l}\text { 1 Teşrinisani } 1315 \\
\text { (13 Kasım 1899) }\end{array}$ & $\begin{array}{l}\text { Sahibi: Mehmed Kemal, } \\
\text { müdürü ve sermuharriri: } \\
\text { A. N. İsmet, } \\
\text { müdürü: F. Ali }\end{array}$ & $\begin{array}{l}\text { Ceride- } i \\
\text { Baytariye ve } \\
\text { Ziraiye }\end{array}$ & $\begin{array}{l}\text { Ahter Matbaası, Artin } \\
\text { Asaduryan Şirket-i } \\
\text { Mürettibiye Matbaası, } \\
\text { Mektebi Sanayi-i Şahane } \\
\text { Matbaası, Karabet Matbaası, } \\
\text { Hanımlara Mahsus Gazete } \\
\text { Matbaası, Mahmud Bey } \\
\text { Matbaası }\end{array}$ & 139 & $\begin{array}{l}\text { On beş } \\
\text { günlük, } \\
\text { haftalık }\end{array}$ & \\
\hline $\begin{array}{l}4 \text { Eylül } 1324 \\
\text { (17 Eylül 1908) }\end{array}$ & $\begin{array}{l}\text { Müessisi: } \\
\text { Suad Muhtar, } \\
\text { Müdürü: Mehmed Salih }\end{array}$ & İstişare & $\begin{array}{l}\text { Şirket-i Mürettibiye ve Artin } \\
\text { Asaduryan Matbaası }\end{array}$ & 27 & Haftalık & $\begin{array}{l}\text { Çarşamba, } \\
\text { Perşembe, } \\
\text { Cumartesi }\end{array}$ \\
\hline $\begin{array}{l}10 \text { Şubat } 1309 \\
\text { (22 Şubat 1894) }\end{array}$ & $\begin{array}{l}\text { Artin Efendi } \\
\text { (Asaduryan), } \\
\text { Mehmed Fuad Bey }\end{array}$ & $\begin{array}{l}\text { Malumât } \\
{[1]}\end{array}$ & Şirket-i Mürettibiye Matbaası & 48 & Haftalık & Perşembe \\
\hline $\begin{array}{l}11 \text { Mayıs } 1311 \\
\text { (23 Mayıs 1895) }\end{array}$ & $\begin{array}{l}\text { Müdürü: } \\
\text { Mehmet Tahir }\end{array}$ & $\begin{array}{l}\text { Malumât } \\
{[2]}\end{array}$ & $\begin{array}{l}\text { Babıali Caddesi } 52 \text { numara } \\
\text { [Artin Asaduryan Matbaası, } \\
\text { Babıali Caddesi } 40 \text { numaralı } \\
\text { daire }\end{array}$ & 423 & Haftalık & Perşembe \\
\hline $\begin{array}{l}1 \text { Eylül } 1324 \\
\text { (14 Eylül 1908) }\end{array}$ & $\begin{array}{l}\text { Müdürü: } \\
\text { Mehmet Ali Bey }\end{array}$ & $\begin{array}{l}\text { Mecmua-i } \\
\text { Fünûn-i } \\
\text { Baytariye }\end{array}$ & $\begin{array}{l}\text { Mekteb-i Tıbbiye-i Askeriye } \\
\text { Matbaası, Mekteb-i Tibbiye-i } \\
\text { Osmaniye Matbaası, } \\
\text { Mekteb-i Tıbbiye-i Şahane } \\
\text { Matbaası, İstanbul Cihan } \\
\text { Matbaası, } \\
\text { Artin Asaduryan ve } \\
\text { Mahdumları Matbaası }\end{array}$ & 24 & $\begin{array}{l}\text { On beş } \\
\text { günlük } \\
(1-12 . \text { sayı } \\
\text { arasi), } \\
\text { Aylik (13-24. } \\
\text { sayı arasında) }\end{array}$ & \\
\hline $\begin{array}{l}17 \text { Mayıs } 1329 \\
\text { (30 Mayıs 1913) }\end{array}$ & $\begin{array}{l}\text { Müessisi: Mağmümî, } \\
\text { Mesul müdürü: } \\
\text { Hüseyin Hâmid }\end{array}$ & Mektebli & $\begin{array}{l}\text { Artin Asaduryan ve } \\
\text { Mahdumları Matbaası, } \\
\text { Resimli Kitap Matbaası, } \\
\text { İttihad ve Ticaret } \\
\text { kütüphanesi, Nefaset } \\
\text { Matbaası, Selanik Matbaası, } \\
\text { Hilal Matbaası, Mahmud Bey } \\
\text { Matbaası }\end{array}$ & 39 & Haftalık & Perşembe \\
\hline $\begin{array}{l}9 \text { Eylül } 1324 \\
\text { (12 Eylül 1908) }\end{array}$ & $\begin{array}{l}\text { Sahibi: Enver, } \\
\text { Yayımlayan: } \\
\text { Abdülkadir }\end{array}$ & $\begin{array}{l}\text { Musavver } \\
\text { Karnaval }\end{array}$ & Artin Asaduryan Matbaası & 1 & Haftalık & Salı \\
\hline
\end{tabular}




\begin{tabular}{|l|l|l|l|l|l|l|}
\hline $\begin{array}{l}\text { 8 Ağustos 1324 } \\
\text { (21 Ağustos 1908) }\end{array}$ & $\begin{array}{l}\text { İmtiyaz sahibi: } \\
\text { Hüseyin Hıfıı }\end{array}$ & $\begin{array}{l}\text { Necmi } \\
\text { Terakki }\end{array}$ & $\begin{array}{l}\text { Hacı Hüseyin Efendi } \\
\text { Matbaas1, Asır Matbaası, } \\
\text { Karacaoğlu Matbaası, Artin } \\
\text { Asaduryan Matbaası, Necmi } \\
\text { İstanbul Matbaası }\end{array}$ & 49 & Haftalık & Perşembe \\
\hline $\begin{array}{l}\text { 21 Haziran 1341 } \\
\text { (21 Haziran 1925) }\end{array}$ & $\begin{array}{l}\text { Mesul müdürü: } \\
\text { Hakkı Nezih }\end{array}$ & Vay Vay & Şirket-i Mürettibiye Matbaası & 3 & Haftalık & Pazar \\
\hline $\begin{array}{l}\text { 1 Mart 1328 } \\
\text { (14 Mart 1912) }\end{array}$ & $\begin{array}{l}\text { Sahibi: M. Şükrü, } \\
\text { Mesul Müdür: } \\
\text { İsmail Hakkı }\end{array}$ & Zafer & $\begin{array}{l}\text { Artin Asaduryan ve } \\
\text { Mahdumları Matbaası, } \\
\text { Nefaset Matbaası }\end{array}$ & 28 & Haftalık & Perşembe \\
\hline
\end{tabular}

\section{Tablo I: Asaduryan'ın bastığı süreli yayınlar}

Görüldüğü üzere Artin Asaduryan Matbaası'nda II. Abdülhamid devrinden Cumhuriyet'in ilk yıllarına kadar geçen süreçte en az on süreli yayın basılmıştır. Bunların adlarının, sorumlularının, yayımlanma aralıklarının ve kaç sayı çıktıklarının dökümü Tablo I'de görülmektedir. Süreli yayınların sayı dağılımı; Asker 29, Aşiyan 26, Ceride 86, İstişare 27, Malumât[1] 48, Malumât[2] 423, Mecmua-i Fünûn-i Baytariye 24, Mektepli 39, Musavver Karnaval 1, Necmi Terakki 49, Vay Vay 3, Zafer 28 sayı şeklindedir. Söz konusu yayınlardan bazıları tamamen Artin Asaduryan Matbaası'nda basilırken, bazı yayınların bazı sayıları farklı matbaalarda da yayımlanmıştır. En uzun yayın hayatında kalmı̧ yayın Malûmat[2] adlı yayındır. En kısa ömürlü yayın ise Musavver Karnavaldir.

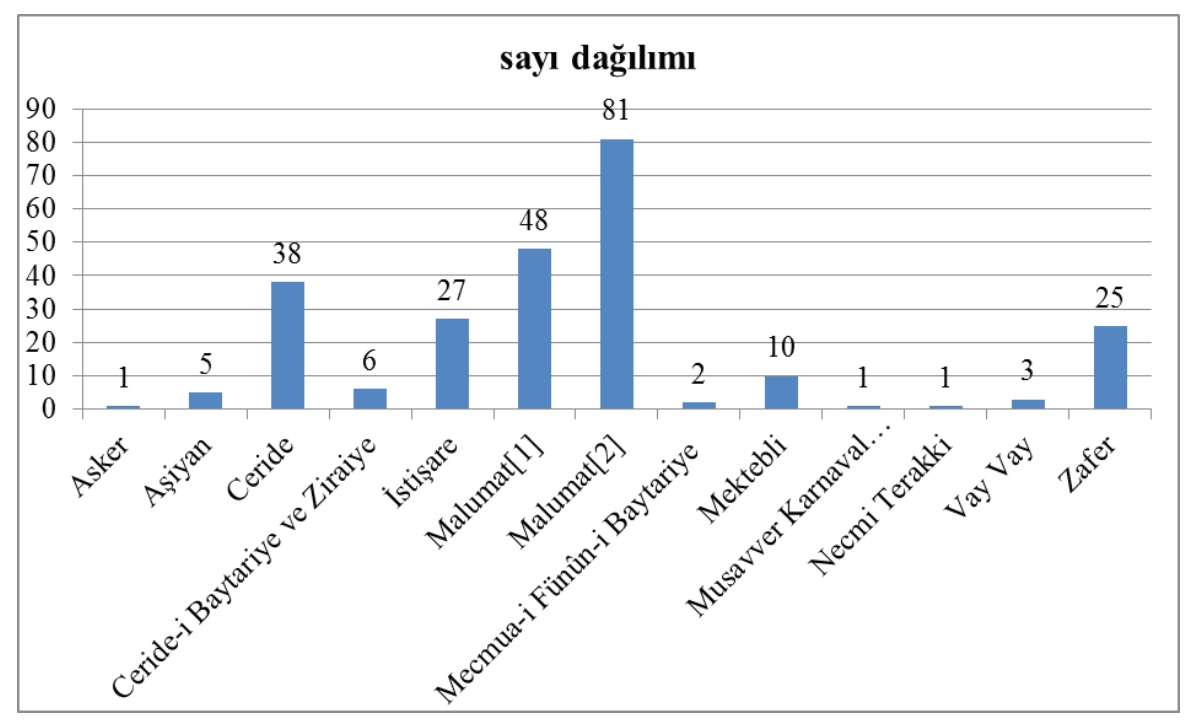

\section{Grafik II: Artin Asaduryan Matbaası'nda basılan sayıların dağılımı}

Grafik II'deki dağılım süreli yayınların basılan sayıları arasında sadece Artin Asaduryan Matbaası'nda, Şirket-i Mürettibiye Matbaası'nda ve Ba- 
bıali Caddesi 52 numaralı matbaada yani Artin Asaduryan'a ait matbaada basılan süreli yayınların dağılımıdır. Artin Asaduryan; Asker'de, Musavver Karnaval'dan, Necm-i Terakkiden 1 sayı, Assiyan'dan 5, Ceride'den 38, Ceride-i Baytariye ve Ziraiye'den 6, İstişare'den 27, Malumat [1]'den 48, Malumat [2]'den 81, Mecmua-i Fünûn-i Baytariye'den 2, Mektebliden 10, Vay Vay'dan 3 ve Zafer'den 25 sayısını basmıştır. Bu süreli yayınların içerisinde İstişare ve Malumat[1]'in tamamı Artin Asaduryan tarafindan basılmıştır. Artin Asaduryan'ın matbaasinda en fazla Malumat [2], en az Asker, Musavver Karnaval ve Necm-i Terakki yayınları basılmıştır.

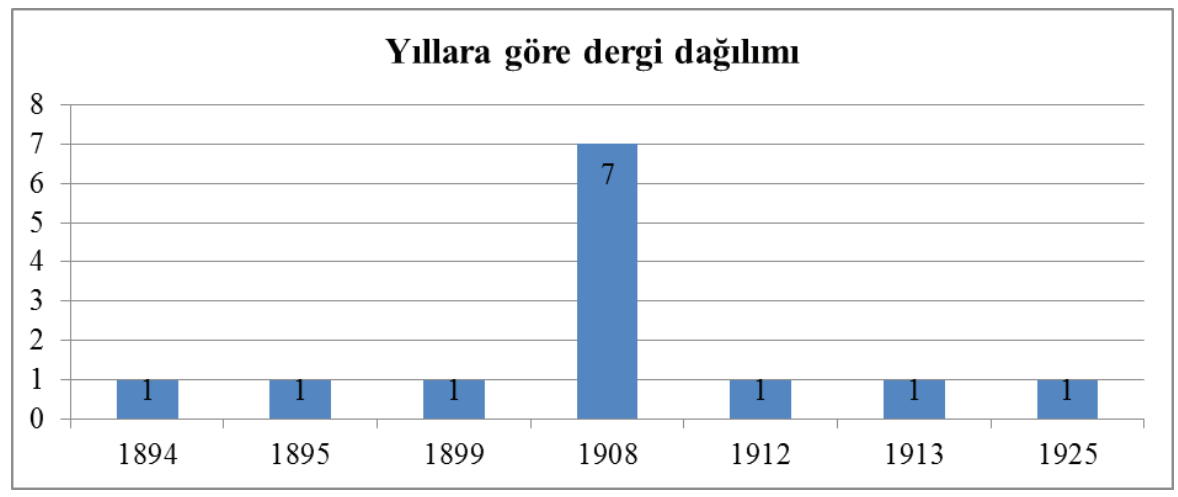

\section{Grafik III: Yıllık süreli yayın dağılımı}

Grafik III'te ise tablo I'deki süreli yayınları ilk çıkış tarihlerine göre yılllk dağılımı görülmektedir. Grafik III’e göre 1894, 1895, 1899, 1912, 1913 ve 1925 yıllarında birer, 1908 yılında ise 7 farklı süreli yayın basılmıştır. Bu süreli yayınların hepsinde Artin Asaduryan Matbaası'nın az veya çok basılmasında katkısı bulunmaktadır. En fazla süreli yayın 1908 yılında basılmıştır. Bu durum, II. Abdülhamid döneminin sansürcü yaklaşımının ardından Meşrutiyet'in sunduğu hürriyetle alakalıdır. Meşrutiyet'in ilan edildiği 24 Temmuz 1908 tarihinden 1909 Ağustos'una kadar geçen bir y1l içinde imtiyazı alınan gazete ve dergi sayısının 310 olduğu ve çoğu yazarın deyimiyle "basın patlaması" yaşandığı hesaba katılırsa bunun sebebi daha iyi anlaşı1ır. İktidarın hürriyet vurgusuna rağmen zaman zaman muhalif yayınlara yasak getirmesi karşısında, muhaliflerin birisi kapatıldığında ertesi gün yenisini hayata geçirmek amacıyla birden fazla gazete imtiyazı alma yoluna sapması söz konusu patlamanın başlıca nedenlerinden birisidir (Gazel ve Ortak 2006: 224). 1909 sonrasının sönük geçmesi de Kocabaşoğlu'nun ifadesiyle "basındaki çölleşme" ile alakalıdır. Zira yayınların çoğu, uzun ömürlü olamamış ve örneğin 1910 yılında İstanbul'da bütün dillerde yayımlanan gazete ve dergilerin sayısı 48'e, bunların içerisinde Türkçe olanların adedi ise 12'ye gerilemiştir (Kocabaşoğlu 2010: 8). 


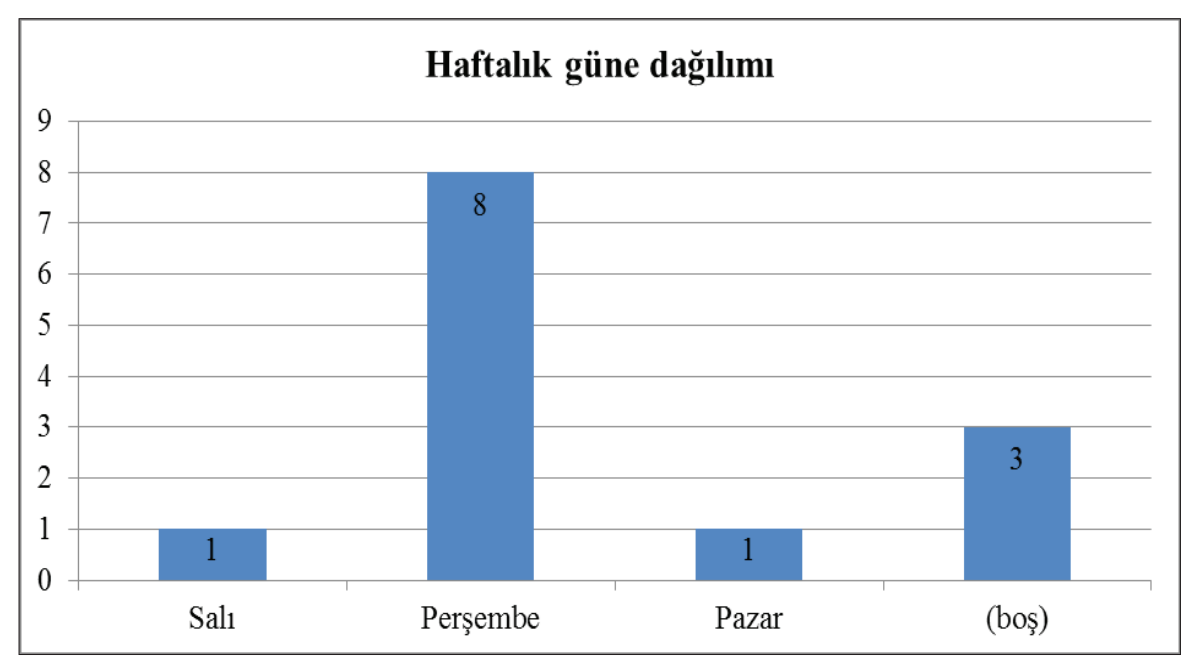

\section{Grafik IV: Süreli yayınların haftalık günü dağılımı}

Grafik IV'te Asaduryan'ında basmı̧̧ olduğu yayınların günlere dağılımı gösterilmiştir. Matbaada haftanın salı ve pazar 1, perşembe günü 8 farklı süreli yayın çıkarılmı̧ olup 3 yayın ise on beş günlük veya bir aylık olarak çıkarılmıştır. Matbaada basılan süreli yayınların haftalık günlere dağılımında perşembe günü dikkat çekmektedir.

\section{Sonuç}

Artin Asaduryan, 19. yüzyılın ikinci yarısında taşradan İstanbul'a göç ederek, payitahtın kültür hayatına değer katmış simalardan birisidir. Osmanlı Devleti'nin bütünlügünü tehdit eden ve etkileri hâlen sürmekte olan "Ermeni Meselesi”nin gelişim sürecine, terör ve anarşi dönemine tanıklık ettiği hâlde, onun ayrilıkçı fikirler yerine, eğitim ve kültür hizmetlerini tercih etmiş olması önemlidir. Asaduryan Matbaası'nda 1889-1928 döneminde farklı türlerde 1417 civarında eser basmıştır. II. Abdülhamid ve II. Meşrutiyet gibi birçok açıdan birbirine zıt iki dönemde faaliyet göstermiş olan Asaduryan 20. yüzyılın başlarında ruhsatsız kitap bastığı için devletten ihtar almış olmasının dışında, nizamnamelere uygun faaliyet yürüttüğünden resmî bir yaptırıma muhatap olmamıştır (BOA, DH. MKT, nr. 497/17; BOA, DH. MKT, nr. 2522/96). Bu durum onun resmî politika paralelinde bir yayın ilkesi benimsemiş olduğu şeklinde yorumlanabilir. Onun en önemli hizmetlerinden birisi de süreli yayın basımına yaptığı katkıdır. Tespitlerimize göre irili ufak1 on iki gazete ve derginin okuyucuyla buluşmasını sağlayan Asaduryan'ın bu bağlamda altı çizilmesi gereken hizmetlerinden birisi, Edebiyat-1 Cedide topluluğunu bir araya getiren genç aydınları Malumat dergisi çatısı altında 
buluşturmuş olmasıdır. Asaduryan Matbaası'nda basılan eserler kendi döneminin aydınlanmasında önemli bir boşluğu doldurduğu gibi, bugün de siyasî tarih, askerî tarih, iktisat tarihi, hukuk tarihi, kültür tarihi, edebiyat, folklor ve sosyoloji alanlarında araştırmacılara temel kaynak teşkil etmektedir.

\section{Kaynaklar}

\section{Başbakanlık Osmanlı Arşivi (BOA) Belgeleri}

Dâhiliye Nezareti Mektubî Kalemi (DH. MKT), nr. 359/20, 27 Şubat 1310.

Dâhiliye Nezareti Mektubî Kalemi (DH. MKT), nr. 497/17, 25 Safer 1320 - 20 Mayı1318.

Dâhiliye Nezareti Mektubî Kalemi (DH. MKT), nr. 2522/96, 29 Rebî́ü'1âhir 1319

\section{Kitap, Makale ve Tezler}

Akçura, Gökhan (2012). Cumburiyet Döneminde Türkiye Matbaacllık Taribi, İstanbul: YKY-Tarih Vakfi-BASEV Ortak Yayını.

Akdemir Örnekkol, Ayşe (2014). "Edebî Yönden Cerîde Dergisinin İncelenmesi”, yayımlanmamış yüksek lisans tezi, Afyon: Afyon Kocatepe Üniversitesi.

Alemdar, Korkmaz (1980). İstanbul (1875-1964) Türkiye'de Yayınlanan Fransızca Bir Gazetenin Taribi, Ankara: A.İ.T.İ.A. Gazetecilik ve Halkla İlişkiler Yüksek Okulu Yayınları.

Ayaydın Cebe, Günil Özlem (2009). “19. Yüzyılda Osmanlı Toplumu ve Basılı Türkçe Edebiyat Etkileşimler, Değişimler, Çeşitlilik", yayımlanmamış doktora tezi, Ankara: Bilkent Üniversitesi

Bal, Alev (2007). "Malûmat Gazetesi (49-72. Sayılar) Tahlilî Fihristi İnceleme ve Seçme Metinler”, yayımlanmamı̧ yüksek lisans tezi, Tokat: Gaziosmanpaşa Üniversitesi.

Birinci, Ali (2006). "Osmanlı Devletinde Matbuat ve Neşriyat Yasakları Tarihine Medhal”, Türkiye Araştırmaları Literatür Dergisi 7, s. 291-349. 148. (1995). "Meşrutiyet Matbuatı (1324-1324)/I”, Kebikeç 2, s. 143-

Deniz, Fatma Banu (2010). “İkinci Meşrutiyet Dönemi Süreli Çocuk Yayınlarında Dinî Motifler (Mektepli, Mini Mini, Çocuk Dostu, Küçükler Gazetesi)", yayımlanmamı̧ yüksek lisans tezi, Isparta: Süleyman Demirel Üniversitesi.

Duman, Hasan (2000). Başlangııından Harf Devrimine Kadar Osmanlı-Türk Süreli Yayınlar ve Gazeteler Bibliyografyası ve Toplu Kataloğu. 18281928, C. 1, Ankara: Enformansyon ve Dokümantasyon Hizmetleri Vakfi. 
(2000). Başlangicından Harf Devrimine Kadar Osmanli-Türk Süreli Yayınlar ve Gazeteler Bibliyografyası ve Toplu Kataloğu. 18281928, C. 2, Ankara: Enformansyon ve Dokümantasyon Hizmetleri Vakfi.

(1986). İstanbul Kütüphaneleri Arap harfli Süreli Yayınlar Toplu Kataloğu 1828-1928, İstanbul: İslam Tarih, Sanat ve Kültür Araştırma Merkezi-İslam Konferansı Teşkilatı.

Ebüzziya, Ziyad (1993). "Ceride”, Diyanet İslam Ansiklopedisi, VII, s. 403404, Ankara: Türkiye Diyanet Vakfi Yayınları.

Galitekin, Ahmed Nezih (2003). Osmanl Kaynaklarna Göre İstanbul: Cami, Tekke, Medrese, Mekteb, Türbe, Hamam, Kütübhâne, Matbaa, Mahalle ve Selâtîn İmâretleri, İstanbul: İ̧̧aret Yayınları.

Gazel, Ahmet Ali ve Şaban Ortak (2006), “İkinci Meşrutiyet’ten 1927 Yılına Kadar Yayın İmtiyazı Alan Gazete ve Mecmualar (1908-1927)”, Atatürk Üniversitesi Sosyal Bilimler Enstitüsü Dergisi, C. 7, 1, s. 223-256.

İgüs, Esma (2008). "II. Abdülhamid Dönemi Eğitim Sistemi, Eğitim Yapılar1 ve Askeri Rüşdiyeler", yayımlanmamış doktora tezi, İstanbul: Yıldız Teknik Üniversitesi.

134 Istanbul Telefon Rebberi-1955-1956.

İzrail, Nesim Ovadya (2013). 24 Nisan 1915 İstanbul, Çankır, Ayaş, Ankara, İstanbul: İletişim Yayınları.

Kocabaşoğlu, Uygur (2010). "Hürriyet"i Beklerken İkinci Meşrutiyet Basını, İstanbul: İstanbul Bilgi Üniversitesi Yayınları.

Koçu, Reşad Ekrem (1959). “Asaduryan (Artin)”, İstanbul Ansiklopedisi, II, s. 1087, İstanbul: İstanbul Ansiklopedisi ve Neşriyat.

(1959). “Ankara Caddesi”, İstanbul Ansiklopedisi, II, s. 862-874, İstanbul: İstanbul Ansiklopedisi ve Neşriyat.

(2007). “Ankara Caddesi”, Müteferrika 32, s. 79-101.

Kültür ve Turizm Bakanlığı (1987). Eski Harfli Türkçe Süreli Yayınlar Toplu Kataloğu, C. I, Ankara: Kültür ve Turizm Bakanlığı, Milli Kütüphane Başkanlığı Yayınları.

Melikoğlu Gölcü, Berfin-Şule Osmanağaoğlu Sanal (2012). Mecmua-i Fünûn-i Baytariye: İnceleme ve Özetli Bibliyografya, Osmanl Bilimi Araștırmaları, XIV/1, s. 46-51.

Mildanoğlu, Zakarya (2014). Ermenice Süreli Yayınlar 1794-2000, İstanbul: Aras Yayıncilik.

Öztürk, Selahattin-Abdurrahman M. Haciismailoğlu-Muhammed Hızarc1 (2006). Hakkı Tarık Us Kütüphanesi Kataloğu Süreli Yayınlar, İstanbul: 
İstanbul Büyükşehir Belediyesi Kültür ve Turizm Daire Başkanlığı Kültür Müdürlüğü. (2010). Beyazıt Devlet Kütüphanesi Hakkı Tarık Us Koleksiyonu Süreli Yayınlar Kataloğu, Kültür ve Turizm Bakanlığı Beyazıt Devlet Kütüphanesi, Tokyo Yabancı Diller Üniversitesi.

Pamukciyan, Kevork (2003). Ermeni Kaynaklarindan Taribe Katkılar IV Biyografileriyle Ermeniler, İstanbul: Aras Yayınc1lı.

Pehlivanlı, Hamit (2005). "Son Dönem Tarih Araştırmalarında Askerî Gazete ve Süreli Yayınların Yeri”, Atatürk Araştırma Merkezi Dergisi 61, s. 243-258.

Safi, Muhammet (2001). “İstanbul'un Taşı Toprağ1 Kültür”, Tarih ve Düşünce 22, s. 52-56.

Schick, İrvin Cemil (2009). “Osmanlı Döneminde Matbuat Kapitalizmi”, Virgül 126, s. 58-63.

Straus, Johann (1993). "İstanbul'da Kitap Yayını ve Basımevleri”, Çev. E. Üyepazarc1, Müteferrika 1, s. 5-17.

Şenkartal, Rebi (1987). “Eski Matbaalar-II”, Basmen Matbaacıllk Dergisi 7-8, s. 54-55.

Teotig (2012). Baskı ve HarfErmeni Matbaacılık Taribi, Çev. S. Malhasyan-A. İncidüzen, İstanbul: Birzamanlar Yayınc1lı.

Uçman, Abdullah (2003). "Ma'lumat”, Diyanet İslam Ansiklopedisi, XXVII, s. 542-543, Ankara: Türkiye Diyanet Vakfi Yayınları.

(2003). "Ma'lumat", Diyanet İslam Ansiklopedisi, XXVII, s. 543545, Ankara: Türkiye Diyanet Vakfı Yayınları.

Yarman, Arsen (2001). Osmanlı Sağllk Hizmetlerinde Ermeniler ve Surp Pırgiç Ermeni Hastanesi Taribi, İstanbul: Surp Pırgiç Ermeni Hastanesi Vakfi Yayın1.

Yazıc1, Nesimi (1983). Takvim-i Vekayi, Ankara: Gazi Üniversitesi Basın Yayın Yüksekokulu Yayını.

(1991). "Vekâyi-i Mısriye", Osmanlı Taribi Araştırma Merkezi Dergisi 2, s. 267-278.

\section{Süreli Yayınlar}

Asker, nr. 1, 21 Ağustos 1324; nr. 2, 1 Eylül 1324, nr. 3, tarih yok.

Aşiyan, nr. 1, 28 Ağustos 1324; nr. 2, 21 Şubat 1326; nr. 8, 10 Şevval 1326; nr. 11, 2 Zilkade 1326; nr. 12, 9 Zilkaade 1326; nr. 16, 6 Zilhicce 1326; nr. 18, 21 Zilhicce 1326; nr. 19, 28 Zilhicce 1326. 
Cerîde, nr. 1, 20 Ramazan 1326; nr. 15, 28 Zilhicce 1326; nr. 17, 22 Kanunisani 1324, nr. 1829 Kanunisani 1324, nr. 19, 5 Şubat 1324, nr. 34, 30 Nisan 1325; nr. 41, 17 Haziran 1325.

Ceride-i Baytariye ve Ziraiye, birinci sene, nr. 1, 1 Teşrinisani 1315; Birinci sene, nr. 5, 1 Kanunisani 1315; Birinci sene, nr. 7, 1 Şubat 1315; İkinci sene, nr. 1, 7 Kanunievvel 1316; Üçüncü sene, nr. 1,3 Kanunisani 1317; Dördüncü sene, nr.1, 2 Kanunisani 1318; Beşinci sene, nr. 1, 4 Mart 1320, Beşinci sene, nr. 11, 20 Mayıs 1320.

İstişâre, nr. 1, 4 Eylül 1324.

Malumât, nr. 1, 10 Şubat 1309; nr. 48, 7 Zilkade 1312.

Malumat, nr. 1, 11 Mayıs 1311; nr. 31-32, 11 Zilkade 1312; nr. 30, 16 Şaban 1313; nr. 31-32, 11 Zilkade 1312; nr. 37, 10 Zilhicce 1313; nr. 38, 17 Zilhicce 1313; nr. 48, 11 Rebiülevvel 1314; nr. 59, 27 Cemaziyelahir 1314; nr. 81, 10 Zilhicce 1314; nr. 82, 17 Zihicce 1314.

Mecmua-i Fünûn-i Baytariye, Birinci sene, nr. 1,1 Eylül 1324; nr. 215 Eylül 1324; nr. 5, 1 Teşrini Sani 1324; Birinci sene, nr. 10, 15 Kanunisani 1324; İkinci sene, nr. 1, 1 Eylül 1325, İkinci sene, nr. 5, Kanunisani 1325.

Mektebli, nr. 1, 15 Mayıs 1329.

Musavver Karnaval, nr. 1, 9 Eylül 1324.

Necm-i Terakki, nr. 1, 23 Receb 1326; nr. 2, 30 Receb 1326; nr. 5, 23 Şaban 1326; nr. 9, 11 Şevval 1326; nr. 49, 1 Ramazan 1327.

Salnâme-i Nezaret-i Maarif-i Umûmiyye (SNMU), Birinci Sene, 1316 Sene-i Hicriyyesine Mahsus, Matbaa-y1 Amire, İstanbul 1316/1898; İkinci Sene, 1316 Sene-i Hicriyyesine Mahsus, Matbaa-yı Amire, İstanbul 1317/1899; Üçüncü Sene, 1318 Sene-i Hicriyyesine Mahsus, Matbaa-y1 Amire, İstanbul 1318/1900; Dördüncü Sene, 1319 Sene-i Hicriyyesine Mahsus, Matbaa-yı Amire, İstanbul 1319/1901; Altınc1 Sene, 1321 Sene-i Hicriyyesine Mahsus, Matbaa-yı Amire, İstanbul 1321/1903.

Vay Vay, nr. 1, 21 Haziran 1925.

Zafer, nr. 1, 25 Rebîulevvel 1330; nr. 10, 29 Cemaziyelevvel 1330; nr. 11, 6 Cemaziyelahir 1330; nr. 26, 7 şevval 1330; nr. 28, 21 Şevval 1330. 


\section{ABSTRACT \\ Periodical Publishing Works and Artin Asaduryan Press in Turkish Press History}

Second Constitutional Period is one of the most fluctuant time of Turkish history and this period stands out in terms of press and publishing as well. Thanks to Constitutional Law, Muslims, non-Muslims and many foreigners started to obtain concession; consequently, newspapers and magazines more than a thousand started to be published. These publishing's are not only unique sources to deal with the political and sociological issues of that time but also contains information for our culture and literary history. This article is about entrepreneur Armenian Artin Asaduryan's cultural activities who played a key role on the improvement of press and journalism in Ottoman period. Artin Asaduryan moved to Istanbul from his hometown, Kayseri, and started to work as a typesetter to make a living in a press. Then he bought Sirket-i Murettibiye Pressing and embarked on his publishing career. In addition to Turkish, there were also books in Romaic, Armenian and European languages and annuals and ten periodicals were published as well. These publishing's were released on a regular basis and their contents included politics, military service, national defense, literature, moral issues, law, diplomacy, culture, notions, science and technical issues, art, pedagogics, humor and etc. In the work which is supported by charts and graphics, the identity information and contents of these publishing will be presented in alphabetical order.

Keywords: Ottoman Empire, Turkish Press History, cultural history, press, Artin Asaduryan 
